\title{
C - REACTIVE PROTEIN: AN INFLAMMATORY BIOMARKER PRESENT IN
} MULTIPLE DISEASE PATHOGENESIS

\section{Parvinder Kaur*}

Research scholar, Department of Biotechnology, Shri Jagdish Prasad Jhabarmal Tibrewala University, Vidyanagari, Rajasthan, India ${ }^{*}$ Corresponding Author

Shri Jagdish Prasad Jhabarmal Tibrewala University, Vidyanagari, Rajasthan, India

Shri Jagdish Prasad Jhabarmal Tibrewala University, Vidyanagari, Rajasthan, India

\section{Prashant Khadke}

ABSTRACT C-reactive protein (CRP) is an acute-phase protein belongs to pentraxins family with a feature of five identical globular subunits. Two different isoforms i.e. pentameric CRP (pCRP) and monomeric CRP (mCRP) have different key role in regulation. The key biological function of CRP is host defense using classical complement pathway against bacterial infection and involved in removal of apoptotic and necrotic cells. Although CRP is mainly associated with inflammation in bacterial infection such as tuberculosis or Pneumococcus infection, however it is also presence in atherosclerosis, cardiovascular disease (CVD) and in various cancers which make it good candidate for prognostic study in different clinical conditions.

KEYWORDS : Complement Pathway, CRP, Host Defense, Inflammation.

\section{INTRODUCTION}

C-reactive protein is an acute-phase inflammatory plasma protein discovered by Tillet and Francis in 1930, while investigating the patients sera having Pneumococcus infection [1]. CRP was named for its capability to precipitate the C-polysaccharide of Streptococcus pneumoniae. [2]. CRP binds to phosphocholine (PCh) on microorganisms which is calcium dependent and it activates the classical complement pathway of innate immunity [3]. The average serum concentration of CRP in a healthy individual is $0.8 \mathrm{mg} / \mathrm{L}$, but different factors including polymorphisms in the CRP gene can affect the base line of CRP in individuals [4]. Other factors are age, gender, smoking habit, lipid profile, weight and hypertension, which also can affect the baseline of CRP levels [5].

The pentameric isoform of CRP is synthesized mainly in hepatocytes however other cells are also able to synthesized CRP including macrophages [6], smooth muscles cells [7], adipocytes and lymphocytes [8] and endothelial cells [9]. Monomeric CRP ( $\mathrm{mCRP}$ ) is building block of pentameric CRP (pCRP) and $\mathrm{mCRP}$ is assembled to form $\mathrm{pCRP}$ in endoplasmic reticulum [10]. CRP is typically considered as critical regulator of the innate immunity and a dominant facilitator of acute-phase response. It is also associated with chronic inflammation in cancer, rheumatologic conditions, tuberculosis and cardiovascular disease [11-13]. CRP protein is primarily synthesized in the liver [14], in response to pro inflammatory cytokines such as IL-6 which seem to be the main regulator for synthesis [15]. The present study summarizes the biological significance and association of $\mathrm{CRP}$ with disease pathogenicity in multiple clinical conditions.

\section{C - REACTIVE PROTEIN: STRUCTURE AND FUNCTION}

Human CRP sequence having 224 amino acids containing signal sequence of 18 amino acid at amino terminal. Mature peptide of CRP contains 206-amino acid which is member of the short pentraxins family with high phylogenetic conservation [16]. Pentraxins family have common structural characteristic including five identical globular subunit and each subunit constituted by two beta pleated sheets that are non-covalently connected and organized in a symmetric cyclic pattern, decisive a pentameric configuration [17, 18]. In circulation, pentameric isoform of $\mathrm{CRP}$ (pCRP) is formed and secreted by the liver [19]. In some condition pentameric CRP (pCRP) gone thorough conformational changes to form monomeric CRP (mCRP) and this $\mathrm{mCRP}$ is significantly less soluble than pCRP [20]. It was reported that lipids are responsible for the dissociation of $\mathrm{pCRP}$ to its monomeric form $\mathrm{mCRP}$. Though the structure and confirmation of $\mathrm{mCRP}$ is not clear and it may form dimer or trimer with distorted confirmation [21].

The pCRP termed as native CRP (nCRP), which has five identical globular subunit with discoid configuration. All five subunits are present in same orientation around the central core with two-layered beta sheet [22]. Each globular subunit have phosphocholine ( $\mathrm{PCh}$ ) binding site [23]. The molecule has characteristic feature of having two calcium ions per subunit and the presence of calcium ions are essential for the high stability and binding to PCh. One face of molecule used to interacts with complement pathway molecule $\mathrm{Clq}$ and participate in activation of classical complement pathway [24]. The pCRP can be irreversibly dissociated to its monomeric form $\mathrm{mCRP}$ and this dissociation was reported in the presence of urea or in the absence of calcium at high temperature $[19,25]$. Both form i.e. pCRP and mCRP have different characteristics including antigenic activity and epitope, biological function and its electrophoretic mobility [26]. The mCRP isoform increase the adherence of platelet to neutrophil cells however pCRP reported to decrease the adherence [27]. Both $\mathrm{pCRP}$ and $\mathrm{mCRP}$ have different affinity for formation of immune complex. The pCRP used to binds to low affinity IgG receptor FcyRIla while $\mathrm{mCRP}$ used to bind FC RIIIa (CD16a) on monocytes and FC RIIIb (CD16b) on neutrophils with low affinity immune complex [28].

\section{CRP: LIGANDS AND RECEPTORS}

Phosphocholine ( $\mathrm{PCh}$ ) is the most well characterized ligand for CRP and this feature is utilizing for purification of protein [17]. Calcium ion is required for the interaction of CRP to PCh of various microorganisms as in case of $\mathrm{C}$-polysaccharide of pneumococcus [29]. PCh is generally not exposed on the cell membrane however in case of membrane damage it exposed because of complement system and available for binding with CRP [30]. Calcium dependent binding of CRP to apoptotic 
cells, increases the binding of $\mathrm{Clq}$ and $\mathrm{C} 3 \mathrm{~b} / \mathrm{bi}$ and hence triggered classical complement pathway. This binding enhances the phagocytosis process of apoptotic cells and this process termed as CRP associated anti-inflammatory response [31, 32]. CRP also reported to bind to chromatin through interactions with histones. Binding of $\mathrm{CRP}$ to $\mathrm{Hl}$ and $\mathrm{H} 2 \mathrm{~A}$ histone is more prominent than other histone protein $\mathrm{H} 2 \mathrm{~B}$, H3 and H4. CRP does not directly bind to DNA $[33,34]$.

\section{CRP DEFENSE MECHANISM}

Complement system is one of the important components of innate immune system which enhance the capability of antibodies and phagocytic cells to remove dead cells and microbial cells form the body using either classical or alternative pathways [35]. In defense mechanism, CRP binds to complement system component $\mathrm{Clq}$ and trigger classical complement cascade. By classical complement pathway, CRP protects the body by clearing pathogenic bacteria including H. influenzae [36] and S. pneumoniae [37]. Apart from innate immunity, CRP also has defense mechanism for histone toxicity released in blood circulation after extensive cell mortality. CRP reduces the damage of endothelial cell induced by histone and coagulation activation. CRP interacts with histones and form complex [38].

Convincing indication from different in vitro studies reveal the CRP-mediated opsonization of modified forms of LDL via Fc receptors by macrophages [39]. In Atherosclerosis, CRP either in monomeric $(\mathrm{mCRP})$ or in pentameric ( $\mathrm{pCRP}$ ) form regulates activation of complement system in the vessel wall and CRP has protective effects by making modified LDL-CRP complex which activates the complement system $[40,41]$.

\section{CRP IN ATHEROSCLEROSIS PATHOPHYSIOLOGY}

Inflammation with the presence of CRP, SAA and fibrinogen are the key factors of pathogenesis of atherosclerosis [42-44]. $\mathrm{CRP}$ is reported as sensitive marker of inflammation and its concentration can elicit up to 1000 folds in inflammation [15]. Many studies report that $\mathrm{C}$-reactive protein is an independent biomarker of atherothrombosis [45] and atherosclerosis [46]. Reports suggested that CRP itself plays are crucial role in atherosclerosis pathogenesis [47]. Endothelial dysfunction is the first step which promotes the formation of atherosclerotic plaque and hence inflammation. In case of injury, endothelial cells express adhesion molecules on cell surface including endothelial leukocyte adhesion molecule-1, intracellular adhesion molecule-l and vascular cell adhesion molecule-l [48].

Few WBCs including T-cells (Tc and Th cells) and monocytes pass through endothelial cell barrier by diapedesis process. In continuation, LDLs accumulate on the site of injury and in gulp by macrophages which form fatty spot. Further proliferation of smooth muscle cells (SMCs) and component of extracellular matrix form a fibrous cap. This morphological spot is called atherosclerotic lesion [49]. Various mediator molecules including cells (endothelial cells, T cells, SMCs), complement factors, inflammatory proteins (ILl, IL6, TNF and CRP) are contributed to develop this lesion, and eventually cause plaque rupture. In atherosclerosis, CRP may be involved by complement activation, monocyte recruitment, vascular cell activation, apoptosis, and thrombosis [50-53].

\section{CRP IN CORONARY HEART DISEASE}

Inflammation is well known factor responsible for the pathogenesis of coronary heart disease (CHD). Various clinical studies demonstrated that CRP is independently predicts cardiovascular malfunctioning and CRP is function as biomarker and a mediator of CHD [54]. Association between acute myocardial infarction (AMI) and high concentration of CRP in serum was first established by de Beer $\mathrm{FC}$ et al. [55]. After extensive clinical studies, CRP was emerging as independent predictor of cardiac malfunctioning and the concentration of serum CRP is directly correlated to AMI and cardiac death [56, 57]. Over few decades it was established that CRP along with lipid profiling (Cholesterol, LDL and HDL) can be a better predictor of the risk of CHD [58, 59].

Patients with high level of CRP from its baseline have high risk of development of myocardial infarction in future. Other inflammatory markers including SAA and IL-6 having similar correlation for AMI occurrence [57, 60]. Potential approach for the reduction of upcoming CHD in person with high CRP level could be usage of statin [61, 62] and aspirin [63]. Based on CRP functions including complement system activation, upregulate of adhesion molecules production, triggering the production of nitric oxide, expression of nitric oxide synthase, CRP cut-points for clinical interpretation was established i.e. CRP concentrations $<0.1 \mathrm{mg} / \mathrm{dl}$ are considered as low, $0.1-0.3$ $\mathrm{mg} / \mathrm{dl}$ considered as average, and $>0.3 \mathrm{mg} / \mathrm{dl}$ considered as high relative risk of CHD [64].

\section{CRP IN CANCER}

Evidences demonstrated that chronic inflammation plays an important role in carcinogenesis in human [65]. CRP, an inflammatory protein, elevate in circulation of cancer patients [66]. Various studies suggest that high concentration of CRP may not be associated with occurrence of cancer however it can increase the risk of carcinogenesis in healthy individual [67-69]. On the study on Danish population, Allin et al. demonstrated that if the CRP concentration of individual measured at baseline, it has 1.3 fold more risk of any cancer type [70]. Two fold risk of occurrence of lung cancer was observed in case of high CRP concentration as compared to low concentration of CRP from baseline [71].

A study on colorectal cancer demonstrated that elevated CRP may increase the risk of cancer up to 1.6 fold [68], however in contrast, no correlation of CRP concentration and occurrence of colorectal cancer was found [72, 73]. Likewise in breast cancer, association was not found between the disease pathogenicity and elevated concentration of CRP from the base level [74]. In case of prostate cancer, primarily the association of elevated level of CRP with disease pathogenicity was reported negative $[73,75]$. So it was found that elevated CRP concentrate may increase the risk of any cancer type mainly lung and colorectal cancer.

\section{CRP IN TUBERCULOSIS}

From last century, incidence of tuberculosis (TB) has been dropped by the rate, approximately $1.5 \%$ per annum. Still TB remains the foremost infectious cause of mortality [76]. Approximate $23 \%$ of TB incidence is reported in India and out of which mortality rate is $1 / 4^{\text {th }}$. It was also reported that approximate $40 \%$ of Indian population have infection of TB however major proportion is latent TB. Recent trend indicated the reduction of TB burden in India however the rate is very slow. Because of geographical hindrance, numerous local cases are left behind the reported data might be because of high rates of recurrence of $\mathrm{TB}$, delay in diagnosis, drug resistance, common symptoms with other disease, inadequate treatment etc. [77]. Xpert MTB/RIF (GXP), a nucleic acid amplification assay or more advance version Xpert MTB/RIF Ultra are common platform for the diagnosis of tuberculosis [78, 79]. However any version of GXP assay cannot be used to measure treatment response of TB.

Acid-fast bacilli (AFB) staining is an alternative to measure therapy response even in the frequent availability of GXP assay [80]. However, $\mathrm{AFB}$ staining is not suitable for the measurement of treatment response of patients who has shown sputum smear negative result [81]. The investigation of CRP level is commonly measured during pathogenicity of 
active tuberculosis (TB) and it is frequently used in South Africa [82, 83]. Various study demonstrated that CRP has lower median in TB as compares to bacterial pneumonia [84]. In several study it was reported that CRP concentration was found at baseline after 2 month of anti TB therapy [85]. These studies suggested the prognostic use of CRP in tuberculosis.

\section{CRP SOURCE}

In inflammation, CRP is measured form serum of patients. So in inflammation condition, blood or other related tissue have elevated concentration of CRP [86, 87]. To make control and calibrator, active human CRP which is pentameric in nature; are purified from non-malignant ascites fluids (AF) and pleural effusion fluid (PF). CRP has calcium dependent affinity to phosphocholine and this feature is used to purify CRP form AF/PF [19]. In malignancy, inflammation would occur in initial or later stage. Independent study on lung, prostate, colorectal and ovarian cancer show association of CRP is disease pathogenicity $[88,89]$ and cancer fluid (CF) is also used for purification of pCRP to make control for immune assay. Monomeric form of CRP (mCRP) from active pentameric purified CRP (pCRP) can be developed with Urea chelation method [25].

Potempa et al. have expressed and purified cys- mutated recombinant $\mathrm{mCRP}\left(\mathrm{r}_{\mathrm{m}} \mathrm{CRP}\right)$ form $E$.coli as host. Protein $\mathrm{r}_{\mathrm{m}} \mathrm{CRP}$ was expressed as inclusion bodies and solubilization was done using citraconyl anhydride [90]. Dortay et. al. expressed the CRP protein in different strains of E.coli including BL21 (DE3), BL21 (DE3) pLysS, BL21 (DE3) Codon Plus-RIL, BL21 Star (DE3) and Rosetta-gami cells however protein was not refolded properly. Further secretory expression of CRP was done in two eukaryotic hosts, namely the yeast Kluyveromyces lactis and the protozoon Leishmania tarentolae. They reported $2 \mathrm{mg} / \mathrm{L}$ of $\mathrm{pCRP}$ form $L$. tarentolae using phosphocholine column purification [91]. This yield is too low for commercializing of recombinant CRP for the preparation of control and calibrator. So for commercial feasibility, higher expression of recombinant active pCRP from yeast and mammalian system is recommended.

\section{DISCUSSION AND CONCLUSIONS}

$\mathrm{CRP}$ is an acute phase protein routinely used for the diagnosis of systemic inflammation. Two different conformational isoforms i.e. pentameric CRP (pCRP) and monomeric CRP (mCRP) have different functions. Mostly pCRP determination is used as an indicator of risk assessment of CVD. The elevated CRP concentration is associated with many malignancies primarily with colorectal cancer and lung cancer. Elevated level of CRP also found in non- malignant ascitic fluid and plural effusion. To make diagnostic platform, CRP is usually purified form ascitic fluid, plural fluid and cancer fluid. Recombinant CRP was expressed in various strain of $E$.coli, yeast $K$. lactis and the protozoon $L$. tarentolae however yield of purified CRP form $L$. tarentolae source is quite low for commercial viability. Current review suggests the routine diagnosis of $\mathrm{CRP}$ concentration for the monitoring of treatment response in various clinical conditions.

\section{CONFLICTS OF INTEREST:}

The authors declare that they have no conflicts of interest.

\section{ACKNOWLEDGEMENTS:}

We thank authors of the primary studies included in this metaanalysis, and Dr. Anuj Kumar Gupta, Department of Recombinant DNA technology, Yashraj Biotechnology Ltd., Navi Mumbai, for his review and valuable feedback on the manuscript.

\section{REFERENCES}

1. Tillet WS, Francis T. Serological reactions in pneumonia with a non- protein somatic fraction of Pneumococcus. J Exp Med 1930; 52(4):561-71.
2. Pepys MB, Baltz, M.L. Acute phase proteins with special reference to Creactive protein and related proteins (pentaxins) and serum amyloid $\mathrm{A}$ protein. Adv Immunol 1983: 34:141-212.

3. Volanakis JE. Human C-reactive protein: expression structure and function. Mol Immunol 2001; 38:189-97.

4. Devaraj S, Venugopal S, Jialal I. Native pentameric C-reactive protein displays more potent pro-atherogenic activities in human aortic endothelial cells than modified C-reactive protein. Atherosclerosis 2006; 184:48-52

5. Hage FG, Szalai AJ. C-reactive protein gene polymorphisms, C-reactive protein blood levels and cardiovascular disease risk. J Am Coll Cardiol 2007; 50(12):1115-22.

6. Devaraj S, Singh U, Jialal I. The evolving role of C-reactive protein in atherothrombosis. Clin Chem 2009; 55(2):229-38.

7. Calabro P, Willerson JT, Yeh ET. Inflammatory cytokines stimulated C-reactive protein production by human coronary artery smooth muscle cells. Circulation 2003; 108(16):1930-2.

8. Calabro P, Chang DW, Willerson JT, Yeh ET. Release of C-reactive protein in response to inflammatory cytokines by human adipocytes: linking obesity to vascular inflammation. J Am Coll Cardiol 2005; 46(6): 1112-3.

9. Pasceri V, Willerson JT, Yeh ET. Direct proinflammatory effect of C-reactive protein on human endothelial cells. Circulation 2000; 102(18):2165-2168.

10. Macintyre S, Samols D, Dailey P. Two carboxyl esterases bind C-reactive protein within the endoplasmic reticulum and regulate its secretion during the acute phase response. J Biol Chem 1994; 269(39):24496-503.

11. Ridker PM. C-Reactive protein: eighty years from discovery to emergence as a major risk marker for cardiovascular disease. Clinical Chemistry, 2009; 55(2): 209-215.

12. Yoon C, Semitala FC, Atuhumuza E, Katende J, et al. Point-of-care C-reactive protein-based tuberculosis screening for people living with HIV: a diagnostic accuracy study. Lancet Infect Dis 2017; 17(12):1285-1292.

13. Dhingra R, Gona $\mathrm{P}$, Nam BH, et al. C-reactive protein, inflammatory conditions, and cardiovascular disease risk. The American Journal of Medicine 2007; 120 (12):1054-1062.

14. Dong Q, Wright JR. Expression of C-reactive protein by alveolar macrophages. J Immunol 1996; 156:4815-4820.

15. Black S, Kushner I, Samols D. C-reactive protein. J Biol Chem 2004; 279(47):48487-48490

16. Mantovani A, Garlanda C, Doni A, Bottazzi B. Pentraxins in innate immunity: From C-reactive protein to the long pentraxin PTX3. J Clin Immun 2008; 28 (1): $1-13$.

17. Thompson D, Pepys MB, Wood SP. The physiological structure of human Creactive protein and its complex with phosphocholine. Structure 1999; 7(2):169-177.

18. Srinivasan N, White HE, Emsley J, Wood SP, Pepys MB, Blundell TL Comparative analyses of pentraxins: implications for protomer assembly and ligand binding. Structure. 1994; 2:1017-1027.

19. Potempa LA, Siegel JN, Fiedel BA, Potempa RT, Gewurz H. Expression, detection and assay of a neoantigen (Neo-CRP) associated with a free human C-reactive protein subunit. Mol Immunol 1987; 24:531-541.

20. Ji SR, Wu Y, Zhu L, Potempa LA, Sheng FL, Lu W, et al. Cell membranes and liposomes dissociate C-reactive protein (CRP) to form a new, biologically active structural intermediate: $\mathrm{mCRP}(\mathrm{m})$. FASEB J 2007; 21:284-294.

21. Crawford JR, Trial J, Nambi V, Hoogeveen RC, Taffet GE, Entman ML. Plasma levels of endothelial microparticles bearing monomeric c-reactive protein are increased in peripheral artery disease. J Cardiovasc Transl Res 2016; 9:184-193.

22. Eisenhardt SU, Thiele JR, Bannasch H, Stark GB, Peter K. C-reactive protein how conformational changes influence inflammatory properties. Cell Cycle 2009; 8(23):3885-92.

23. Boncler M, Watala C. Regulation of cell function by isoforms of C-reactive protein: a comparative analysis. Acta Biochim Pol 2009; 56(1): 17-31.

24. Du Clos TW, Mold C. C-reactive protein: an activator of innate immunity and a modulator of adaptive immunity. Immunol Res 2004; 30(3):261-77.

25. Potempa LA, Maldonado BA, Laurent P, Zemel ES, Gewurz H. Antigenic, electrophoretic and binding alterations of human C-reactive protein modified selectively in the absence of calcium. Mol Immunol 1983; 20(11):1165-75.

26. Wu Y, Potempa LA, El Kebir D, Filep JG. C-reactive protein and inflam-mation conformational changes affect function. Biol Chem 2015; 396(11): 1181-97.

27. Khreiss T, Jozsef L, Potempa LA, Filep JG. Opposing effects of C-reactive protein isoforms on shear-induced neutrophil-platelet adhesion and neutrophil aggregation in whole blood. Circulation 2004; 110(17):2713-20.

28. Du Clos TW. Pentraxins: structure, function and role in inflammation. ISRN Inflamm 2013; 2013:1-22.

29. Volanakis JE, Kaplan MH. Specificity of C-reactive protein for choline phosphate residues of pneumococcal C-polysaccharide. Proc Soc Exp Biol Med 1971; 136:612-614

30. Li YP, Mold C, Du Clos TW. Sublytic complement attack exposes C-reactive protein binding sites on cell membranes. J Immunol 1994; 152: 2995- 3005.

31. Mold C., Baca R, Du Clos TW. Serum amyloid P component and C-reactive protein opsonize apoptotic cells for phagocytosis through Fcg receptors. J Autoimmun 2002: 19: 147-154.

32. Gershov D, Kim S, Brot N, Elkon KB. C-reactive protein binds to apoptotic cells, protects the cells from assembly of the terminal complement components, and sustains an anti-inflammatory innate immune response: implications for systemic autoimmunity. J Exp Med 2000; 192: 1353- 1363.

33. Robey FA, Jones KD, Tanaka T, Liu TY. Binding of C-reactive protein to chromatin and nucleosome core particles. A possible physiological role of Creactive protein. J Biol Chem 1984; 259: 7311-7316.

34. Du Clos TW, Zlock LT, Rubin RL. Analysis of the binding of C-reactive protein to histones and chromatin. J Immunol 1988; 141:4266-4270.

35. Nesargikar PN, Spiller B, Chavez R. The complement system: history pathways, cascade and inhibitors. Eur J Microbiol Immunol 2012; 2(2): 103-111.

36. Weiser JN, Pan N, McGowan KL, Musher D, Martin A, Richards J. Phosphoryl choline on the lipopolysaccharide of Haemophilus influenzae contributes to persistence in the respiratory tract and sensitivity to serum killing mediated 
by C-reactive protein. J Exp Med 1998; 187: 631-640

37. Mold C, Nakayama S, Holzer TJ, Gewurz H, Du Clos TW. C-reactive protein is protective against Streptococcus pneumoniae infection in mice. J Exp Med 1981; 154: 1703-1708.

38. Abrams ST, Zhang N, Dart C, Wang SS, Thachil J, Guan Y, Wang G, Toh CH. Human CRP defends against the toxicity of circulating histones. J Immunol 2013; 191(5):2495-502.

39. Zwaka TP, Hombach V, Torzewski J. C-reactive protein mediated low density lipoprotein uptake by macrophages: implications for atherosclerosis. Circulation 2001; 103(9): 1194-1197.

40. Ji SR, Wu Y, Potempa LA, Liang YH, Zhao J. Effect of modified C-reactive protein on complement activation: a possible complement regulatory role of modified or monomeric C-reactive protein in atherosclerotic lesions. Arterioscler Thromb Vasc Biol 2006; 26(4):935-41.

41. Bhakdi S, Torzewski M, Paprotka K, et al. Possible protective role for Creactive protein in atherogenesis: complement activation by modified lipoproteins halts before detrimental terminal sequence. Circulation 2004; 109(15) 1870-1876.

42. Ross R. Atherosclerosis- an inflammatory disease. N Engl J Med 1999;340:115-26.

43. Gabay C, Kushner I. Acute-phase proteins and other systemic responses to inflammation. N Engl J Med 1999;340:448-54.

44. Uhlar CM, Whitehead AS. Serum amyloid A, the major vertebrate acutephase reactant. Eur JBiochem 1999;265:501-23.

45. Pepys MB, Hirschfield GM. C-reactive protein and atherothrombosis. Ital Heart J 2001;2:196-9.

46. Libby P, Ridker PM. Inflammation and atherosclerosis: role of C-reactive protein in risk assessment. Am J Med 2004; 116 (6):9-16.

47. Jialal Il, Devaraj S, Venugopal SK. C-reactive protein: risk marker or mediator in atherothrombosis? Hypertension 2004; 44, 6-11.

48. Kasper HU, Schmidt A, Roessner A. Expression of the adhesion molecules ICAM, VCAM, and ELAM in the arteriosclerotic plaque. Gen Diagn Pathol 1996; 141:289-94.

49. Ross R. Atherosclerosis is an inflammatory disease. Am Heart J 1999; 138:S419-20.

50. Lombardo A, Biasucci LM, Lanza GA, Coli S, Silvestri P, Cianflone D, et al. Inflammation as a possible link between coronary and carotid plaque instability. Circulation 2004;109:3158-63.

51. Libby P, Sukhova G, Lee RT, Galis ZS. Cytokines regulate vascular functions related to stability of the atherosclerotic plaque. J Cardiovasc Pharmacol 1995;25(Suppl 2):S9-12

52. Speidl WS, Exner M, Amighi J, Kastl SP, Zorn G, Maurer G, et al. Complement component $\mathrm{C} 5 \mathrm{a}$ predicts future cardiovascular events in patients with advanced atherosclerosis. Eur Heart J 2005, 2294 -9.

53. Kassirer M, Zeltser D, Prochorov V, Schoenman G, Frimerman A, Keren G, et al. Increased expression of the CDllb/CD18 antigen on the surface of peripheral white blood cells in patients with ischemic heart disease: further evidence for smoldering inflammation in patients with atherosclerosis. Am Heart J 1999;138:555-9.

54. Shrivastava AK, Singh HV, Raizada A, Singh SK. C-reactive protein, inflammation and coronary heart disease. Egyp Heart J 2015; 67, 89-97.

55. de Beer FC, Hind CRK, Fox KM, Allan R, Maseri A, Pepys MB. Measurement of serum C-reactive protein concentration in myocardial ischaemia and infarction. Br Heart J 1982;47:239-43.

56. Casas JP, Shah T, Hingorani AD, Danesh J, Pepys MB. C-reactive protein and coronary heart disease: a critical review. J Int Med 2008;264:295-314.

57. Ridker PM, Hennekens CH, Buring JE, Rifai N. C-reactive protein and other markers of inflammation in the prediction of cardiovascular disease in women. N Engl J Med 2000;342:836-43.

58. Ridker PM, Glynn RJ, Hennekens CH. C-reactive protein adds to the predictive value of total and HDL cholesterol in determining risk of first myocardial infarction. Circulation 1998;97:2007-11.

59. Danesh J, Whincup P, Walker M, Lennon L, Thomson A, Appleby P, et al. Low grade inflammation and coronary heart disease: prospective study and updated meta-analyses. BMJ 2000;321: 199-204.

60. Ridker PM, Stampfer MJ, Rifai N. Novel risk factors for systemic atherosclerosis: a comparison of C-reactive protein, fibrinogen, homocysteine, lipoprotein( $\alpha)$, and standard cholesterol screening as predictors of peripheral arterial disease. JAMA 2001; 285: 2481-5.

61. Ridker PM, Rifai N, Pfeffer MA, Sacks FM, Moye LA, Goldman S, et al Inflammation, pravastatin, and the risk of coronary events after myocardial infarction in patients with average cholesterol levels. Cholesterol and Recurrent Events (CARE) Investigators. Circulation 1998;98:839-44.

62. Ridker PM, Rifai N, Clearfield M, Downs JR, Weis SE, Miles JS, et al. Measurement of $\mathrm{C}$-reactive protein for the targeting of statin therapy in the primary prevention of acute coronary events. N Engl J Med 2001;344:1959-65.

63. Ikonomidis I, Andreotti F, Economou E, Stefanadis C, Toutouzas P, Nihoyannopoulos P. Increased proinflammatory cytokines in patients with chronic stable angina and their reduction by aspirin. Circulation 1999;100:793-8.

64. Pearson TA, Mensah GA, Alexander RW, Anderson JL, Cannon RO III, Criqui $\mathrm{M}$, et al. Markers of inflammation and cardiovascular disease: application to clinical and public health practice: a statement for healthcare professionals from the Centers for Disease Control and Prevention and the American Heart Association. Circulation 2003;107:499-511.

65. Coussens LM, Werb Z. Inflammation and cancer. Nature 2002:420:860-867.

66. Heikkila K, Ebrahim S, Lawlor DA. A systematic review of the association between circulating concentrations of $\mathrm{C}$ reactive protein and cancer. $\mathrm{J}$ Epidemiol Community Health 2007;61:824-833.

67. Gunter MJ, Stolzenberg-Solomon R, Cross AJ, Leitzmann MF Weinstein S, Wood RJ et al. A prospective study of serum C-reactive protein and colorectal cancer risk in men. Cancer Res 2006;66:2483-2487.

68. Otani T, Iwasaki M, Sasazuki S, Inoue M, Tsugane S. Plasma C-reactive protein and risk of colorectal cancer in a nested case-control study: Japan Public Health Center-based prospective study. Cancer Epidemiol Biomarkers Prev 2006; 15:690-695.
69. Heikkila K, Silander K, Salomaa V, Jousilahti P, Koskinen S, Pukkala E, et al. Creactive protein-associated genetic variants and cancer risk: Findings from FINRISK 1992, FINRISK 1997 and Health 2000 studies. Eur J Cancer 2011;47:404-412.

70. Allin KH, Bojesen SE, Nordestgaard BG. Baseline C-reactive protein is associated with incident cancer and survival in patients with cancer. J Clin Oncol 2009:27:2217-2224.

71. Chaturvedi AK, Caporaso NE, Katki HA, Wong HL, Chatterjee N, Pine SR, et al. C-reactive protein and risk of lung cancer. J Clin Oncol 2010;28:2719-2726.

72. Zhang SM, Buring JE, Lee IM, Cook NR, Ridker PM. C-reactive protein levels are not associated with increased risk for colorectal cancer in women. Ann Intern Med 2005; 142:425-432.

73. Siemes C, Visser LE, Coebergh JW, Splinter TA, Witteman JC, Uitterlinden AG, et al. C-reactive protein levels, variation in the C-reactive protein gene, and cancer risk: The Rotterdam Study. J Clin Oncol 2006;24:5216-5222.

74. Zhang SM, Lin J, Cook NR, Lee IM, Manson JE, Buring JE, et al. C-reactive protein and risk of breast cancer. J Natl Cancer Inst 2007;99:890-894.

75. Platz EA, De Marzo AM, Erlinger TP, Rifai N, Visvanathan K, Hoffman $\mathrm{SC}$, et al. No association between pre-diagnostic plasma C-reactive protein concentration and subsequent prostate cancer. Prostate 2004;59:393-400.

76. World Health Organization. Geneva, Switzerland: WHO; 2016. Global Tuberculosis Report. Available from: http://apps.who.int/iris /bitstream/10665/250441/1/9789241565394-eng.pdf?ua =1.

77. National strategic plan for tuberculosis: 2017-25 elimination by 2025. from https:// www.tbcindia.gov.in./WriteReadData/ National\%20Strategic\% 20Plan\%202017-25. pdf.

78. Dorman SE, Schumacher SG, Alland D, et al; study team. Xpert MTB/RIF Ultra for detection of Mycobacterium tuberculosis and rifampicin resistance: a prospective multicentre diagnostic accuracy study. Lancet Infect Dis 2018; 18:76-84.

79. Steingart KR, Schiller I, Horne DJ, et al. Xpert ${ }^{\circledR}$ MTB/RIF assay for pulmonary tuberculosis and rifampicin resistance in adults. Cochrane Database Sys Rev 2014; 1:CD009593.

80. Friedrich SO, Rachow A Saathoff $E$, et al: Pan African consortium for the evaluation of anti-tuberculosis antibiotics (panacea). Assessment of the sensitivity and specificity of Xpert MTB/RIF assay as an early sputum biomarker of response to tuberculosis treatment. Lancet Respir Med 2013, $1: 462-70$.

81. Treatment of Tuberculosis Guidelines. 4th ed. Geneva: World Health O r g a n i z a t i o n ; $\quad 2010$. http://www.who.int/tb/publications/2010/9789241547833/en/. Accessed 17 October 2018.

82. Agassandian M, Shurin GV, Ma Y, Shurin MR. C-reactive protein and lung diseases. Int J Biochem Cell Biol 2014;53:77-88.

83. Drain PK, Mayeza L, Bartman P et al. Diagnostic accuracy and clinical role of rapid C-reactive protein testing in HIV-infected individuals with presumed tuberculosis in South Africa. Int J Tuberc Lung Dis 2014; 18:20-6.

84. Kang YA, Kwon SY, Yoon HI, Lee JH, Lee CT. Role of C-reactive protein and procalcitonin in differentiation of tuberculosis from bacterial community acquired pneumonia. Korean J Intern Med. 2009;24(4):337-42.

85. Mendy J, Togun T, Owolabi O, et al. C-reactive protein, Neopterin and Beta2 microglobulin levels pre and post TB treatment in the Gambia. BMC Infect Dis 2016; 16(115): 1-6.

86. Ma X, Ji S-R, Wu Y. Regulated conformation changes in C-reactive protein orchestrate its role in atherogenesis. Chin Sci Bull 2013;58:1642-1649.

87. Marnell L, Mold C, DuClos TW. C reactive protein: ligands, receptors and role in inflammation. Clin Immunol 2005; 117:104-111.

88. Shiels MS, Katki HA, Hildesheim A, et al. Circulating inflammation markers, risk of lung cancer, and utility for risk stratification. J Natl Cancer Inst 2015;107: 1-9.

89. Muller DC, Larose TL, Hodge A, Guida F, Langhammer A, et al. Circulating high sensitivity $\mathrm{C}$ reactive protein concentrations and risk of lung cancer: nested case-control study within Lung Cancer Cohort Consortium. BMJ. 2019 Jan 3;364:k4981.

90. Potempa LA, Yao ZY, Ji SR, Filep JG, Wu Y. Solubilization and purification of recombinant modified C-reactive protein from inclusion bodies using reversible anhydride modification. Biophys Rep. 2015;1:18-33.

91. Dortay H, Schmöckel SM, Fettke J, Mueller-Roeber B., Expression of human Creactive protein in different systems and its purification from Leishmania tarentolae. Protein Expr Purif. 2011;78(1):55-60. 